\title{
The Major Factor of Hypertension, Study Case at Posbindu Cipayung, East Jakarta
}

\author{
$1^{\text {st }}$ Cicilia Nurteta \\ Directorate General of \\ Prevention and Control Disease \\ Health Ministry, Republic of \\ Indonesia \\ Jakarta, Indonesia \\ cicilia.naali@yahoo.com
}

\author{
$2^{\text {nd }}$ Atik Kridawati \\ Public Health Science \\ Graduate Program \\ Universitas Respati Indonesia \\ Jakarta, Indonesia \\ atik@urindo.ac.id
}

\begin{abstract}
The objective study to explains the relationship between physical activity, family history, age, obesity and stress with hypertension. The research method is a quantitative study with cross-sectional study design. The population in this study are Posbindu visitors who are aged $>15$ years in Cipayung District, East Jakarta. The sample taken proportionally from the number of visitors Posbindu ( $\mathrm{n}=\mathbf{2 1 0}$ person). Data analysis was done by univariate, bivariate (chi square) and multivariate with multiple logistic regression. The variable influence of hypertension were a family history, age, physical activity, obesity and stress. The dominant factor of hypertension was physical activity with $\mathrm{OR}=4,5(95 \%$ CI: 2,14-9,28). In this study there are confounding variable: consumption of salt/sodium, gender and smoking. The conclusion that people with less physical activity are at higher risk of developing hypertension than people with moderate physical activity.
\end{abstract}

Keywords-family history, hypertension, obesity, physical activity and stres.

\section{INTRODUCTION}

Non Communicable Diseases (PTM) is the main cause of death globally in developed and developing countries. WHO data show that the 57 million deaths occurring in the world in 2008,36 million or nearly two thirds were caused by Noncommunicable diseases. PTM also kills the population at younger age. The proportion of causes of PTM death in people younger than 70 years old, cardiovascular disease is the biggest cause (39\%) [1]. The proportion of mortality due to PTM include heart and blood vessel disease such as Hypertension and Diabetes Mellitus [2].

Hypertension is a condition the blood pressure in blood vessels increases chronically. This can happen because the heart works harder to pump blood to get of oxygen and nutrients the body. Today's hypertensive disease is a big and serious problem, because the prevalence of hypertension is high and tends to increase[2].

Based on data from Riskesdas (2013) [2], hypertension prevalence in Indonesia is $25,8 \%$ with hypertension diagnosis coverage by health manpower reach $36,8 \%$, or in other words most of hypertension in society has not been diagnosed reach 63,2. While the case of Hypertension in DKI Jakarta Province has a high prevalence of 20.0\% [2]. The PTM surveillance system in East Jakarta classifies new cases of hypertension by 2016 amounting to 52.288 cases. The highest new cases of hypertension during 2016 are located at Cipayung District Health Center 9.264 with total visit number 23.499 cases [3].

Hypertension risk factors consist of 1) Risk factors that can not be changed or modified: age, familyhistory, and gender. 2) Risk factors that can be changed or modified: smoking habit, obesity, lackof physical activity, alcohol and excess salt consumption [4].

Based on the recapitulation of integrated coaching center (Pos Pembinaan Terpadu, Posbindu) PTM results in East Jakarta Sub-Dept. Of Health in 2016, some of the most prevalent risk factors are central obesity withmeasurement of abdominal circumference ( $>80 \mathrm{~cm}$ for women, and $>90 \mathrm{~cm}$ for men) with prevalence of $26.78 \%$, followed by obesity (BMI $\geq 25$ ) with prevalence of $21.59 \%$, less physical activity with prevalence $10,64 \%$, less eating vegetables/ fruits $10.14 \%$, stress $3 \%$ and smoking at $1.79 \%$. This suggests that risk factors for non-infectious diseases, especially hypertension is quite high [3].

The aim of the study was to explain the relation of age, family history, smoking, obesity, physical activity, stress, alcohol, and excessive salt intake with hypertension.

\section{MATERIALS AND METHODS}

This research is a quantitative study with cross sectional design. The dependent variable is hypertension. The independent variables are obesity, physical activity, stress, salt consumption, smoking, age, family history, gender.

The number of sample is 210 people from 10 Posbindu in District Cipayung. Inclusion criteria are 15 year olds, visiting Posbindu and willing to be respondents. Exclusion criteria are: in the condition of pregnant, consumption of hypertension medication, suffer stroke, heart disease. Sampling by accidental sampling.

The primary data were collected by interview for variable age, family history, smoking, physical activity, stress with Stress Reporting Questionaire (SRQ), and excessive salt consumption by Food Frequency Questionaire (FFQ). Obesity 
is measured by body mass index (measuring body height and weight). Hypertension variables were measured using a digital tensimeter performed three times the measurement.

Data analysis using Chi-Square test. Then multivariate analysis by multiple logistic regression. All independent variables that become candidates are incorporated into multivariate analysis $(\mathrm{P}<0.25)$.

\section{RESULTS AND DISCUSSION}

The research was conducted in ten Posbindu Sub district of Cipayung spread in 8 villages. From the result of bivariate analysis and continued with multivariate analysis showed that from eight variables studied were found independent variable related to hypertension occurrence is obesity (IMT), less of physical activity, age $\geq 40$ years, family history of hypertension and stress.

Table 1 shows that the number of respondents who suffer from hypertension is $144(68.6 \%)$ more than the respondents who are not hypertension (normal) is $66(31,4 \%)$. There is one independent variable homogeneous: age $<40$ at $13.3 \%$ (porportion $<15 \%$ ). Furthermore, there is a proportion of obesity (IMT $\geq 25$ ) of $57.1 \%$, lack of physical activity by $54.3 \%$, stress $58.6 \%$, excessive salt / sodium intake $73.3 \%$, proportion of smoking $34.3 \%$, age $\geq 40$ years of $86.7 \%$, there is a history family hypertension of $43.3 \%$ and $36.2 \%$ for male.

TABLE I. DISTRIBUTION OF FREQUENCY OF RESPONDENTS BY BLOOD PRESSURE, OBESITY, PHYSICAL ACTIVITY, SALT CONSUMPTION, SMOKING, AGE, FAMILY HISTORY, GENDER

\begin{tabular}{|l|l|l|}
\hline Variable & Hypertension & $\mathrm{n}(\%)$ \\
\hline \multirow{2}{*}{ Blood Pressure } & Not Hypertension & $144(68,6)$ \\
\hline \multirow{2}{*}{ Obesity(BMI>25) } & Obesity & $120(57,1)$ \\
\cline { 2 - 3 } & Not Obesity & $90(42,9)$ \\
\hline \multirow{2}{*}{ Physical Activity } & Less & $(54,3)$ \\
\cline { 2 - 3 } & Moderate & $96(45,7)$ \\
\hline \multirow{2}{*}{ Stress } & Stress & $123(58,6)$ \\
\cline { 2 - 3 } & Not Stress & $87(41,4)$ \\
\hline \multirow{2}{*}{ Salt Consumption } & Excessive & $154(73,3)$ \\
\cline { 2 - 3 } & Not excessive & $56(26,7)$ \\
\hline \multirow{2}{*}{ Smoking } & Smoke & $72(34,3)$ \\
\cline { 2 - 3 } Ages & Not Smoke & $138(65,7)$ \\
\hline \multirow{3}{*}{ Family History } & $\geq 40$ Years & $182(86,7)$ \\
\cline { 2 - 3 } & $<40$ Years & $28(13,3)$ \\
\hline \multirow{2}{*}{ Gender } & $\begin{array}{l}\text { There are Family } \\
\text { History }\end{array}$ & $91(43,3)$ \\
\cline { 2 - 3 } & $\begin{array}{l}\text { There are not family } \\
\text { history }\end{array}$ & $119(56,7)$ \\
\hline & Male & $(36,2)$ \\
\cline { 2 - 3 } & Female & $134(63,8)$ \\
\hline
\end{tabular}

Bivariate analysis using Chi Square (table 2) showed that gender did not have a significant relation with the incidence of hypertension $(p>0.05)$. Male and female have the same risk for hypertension.
TABLE II. THE RELATIONSHIP BETWEEN OBESITY, PHYSICAL ACTIVITY, STRESS, SALT CONSUMPTION, SMOKING HABITS, AGE, FAMILY HISTORY, GENDER WITH HYPERTENSION

\begin{tabular}{|c|c|c|c|c|c|}
\hline \multicolumn{2}{|l|}{ Variable } & Hypertension & $\begin{array}{l}\text { Not } \\
\text { Hypertension }\end{array}$ & $\begin{array}{l}\text { OR } \\
(95 \% \\
\text { CI) }\end{array}$ & $\mathrm{p}$ \\
\hline \multirow[b]{2}{*}{ Obesity(BMI>25) } & Obesity & $96(66,7)$ & $24(36,4)$ & \multirow{2}{*}{$\begin{array}{l}3,5 \\
(1,91- \\
6,44)\end{array}$} & \multirow[b]{2}{*}{0,00} \\
\hline & $\begin{array}{l}\text { Not } \\
\text { Obesity }\end{array}$ & $48(33,3)$ & $42(63,6)$ & & \\
\hline \multirow{2}{*}{ Physical Activity } & Less & $90(62,5)$ & $24(36,4)$ & \multirow{2}{*}{$\begin{array}{l}2,92 \\
(1,59- \\
5,34)\end{array}$} & \multirow{2}{*}{0,00} \\
\hline & Moderate & $54(37,5)$ & $42(63,6)$ & & \\
\hline \multirow[b]{2}{*}{ Stress } & Stress & $95(66)$ & $28(42,4)$ & \multirow{2}{*}{$\begin{array}{l}2,63 \\
(1,45- \\
4,78)\end{array}$} & \multirow[b]{2}{*}{0,001} \\
\hline & $\begin{array}{l}\text { Not } \\
\text { Stress }\end{array}$ & $49(34)$ & $38(57,6)$ & & \\
\hline \multirow[b]{2}{*}{ Salt Consumption } & Excessive & $114(79,2)$ & $40(60,6)$ & \multirow{2}{*}{$\begin{array}{l}2,47 \\
(1,31- \\
4,47)\end{array}$} & \multirow[b]{2}{*}{0,005} \\
\hline & $\begin{array}{l}\text { Not } \\
\text { excessive }\end{array}$ & $30(20,8)$ & $26(39,4)$ & & \\
\hline \multirow[b]{2}{*}{ Smoking } & Smoke & $57(39,6)$ & $15(22,7)$ & \multirow{2}{*}{$\begin{array}{l}2,23 \\
(1,42- \\
4,33)\end{array}$} & \multirow[b]{2}{*}{0,017} \\
\hline & $\begin{array}{l}\text { Not } \\
\text { Smoke }\end{array}$ & $87(60,4)$ & $51(77,3)$ & & \\
\hline \multirow{2}{*}{ Ages } & $\begin{array}{l}\geq 40 \\
\text { Years }\end{array}$ & $131(91)$ & $51(77,3)$ & \multirow{2}{*}{$\begin{array}{l}2,96 \\
(1,32- \\
6,66)\end{array}$} & \multirow{2}{*}{0,007} \\
\hline & $\begin{array}{l}<40 \\
\text { Years }\end{array}$ & $13(9)$ & $15(22,7)$ & & \\
\hline \multirow[b]{2}{*}{ Family History } & $\begin{array}{l}\text { There are } \\
\text { Family } \\
\text { History }\end{array}$ & $74(51,4)$ & $17(25,8)$ & \multirow{2}{*}{$\begin{array}{l}3,41 \\
(1,61- \\
5,79)\end{array}$} & \multirow[b]{2}{*}{0,001} \\
\hline & $\begin{array}{l}\text { There are } \\
\text { not } \\
\text { family } \\
\text { history }\end{array}$ & $70(48,6)$ & $49(74,2)$ & & \\
\hline \multirow[b]{2}{*}{ Gender } & Male & $56(38,9)$ & $20(30,3)$ & \multirow{2}{*}{$\begin{array}{l}1,46 \\
(0,79- \\
2,73)\end{array}$} & \multirow[b]{2}{*}{0,229} \\
\hline & Female & $88(61,1)$ & $46(69,7)$ & & \\
\hline
\end{tabular}

Obese respondents (BMI> 25) had a risk of 3.5 times more hypertension than non-obese. Less of physical activity is at risk 3 times affected by hypertension compared with moderate physical activity. Stress risks triggering hypertension 2.6 times compared with no stress. Consumption of excess salt risk 2.5 times trigger hypertension. Smoking risks 2.2 times more hypertension than non-smokers. People aged over 40 years are at risk 3 times affected by hypertension. Respondents who had a family history of hypertension would have 3.4 times greater risk of hypertension than those without family history of hypertension (Table 2).

TABLE III. BIVARIAT SELECTION

\begin{tabular}{|l|l|l|}
\hline Variable & P Value & Information \\
\hline Obesity & 0,000 & \\
\hline Physical Activity & 0,000 & \multirow{3}{*}{ Candidate } \\
\hline Stress & 0,001 & \\
\cline { 1 - 2 } Salt Consumption & 0,005 & \\
\cline { 1 - 2 } Smoking & 0,007 & \\
\hline Ages & 0,017 & \\
\hline Family History & 0,001 & \\
\hline Gender & 0,229 & \\
\hline
\end{tabular}


TABlE IV. Multivariate ANAlysis (FIRST MOdEls) THE RELATES FACTORS WITH HYPERTENSION

\begin{tabular}{|l|c|l|l|l|}
\hline \multirow{2}{*}{ Variable } & \multirow{2}{*}{ P Value } & \multirow{2}{*}{ Exp (B) } & \multicolumn{2}{|l|}{ 95\% CI FOR EXP (B) } \\
\cline { 4 - 5 } & & & Lower & Upper \\
\hline Obesity & 0,004 & 2,936 & 1,419 & 6,072 \\
\hline Physical Activity & 0,001 & 3,506 & 1,620 & 7,588 \\
\hline Stress & 0,017 & 2,400 & 1,166 & 4,939 \\
\hline Salt Consumption & 0,142 & 1,809 & 0,820 & 3,993 \\
\hline Smoking & 0,009 & 3,846 & 1,470 & 10,517 \\
\hline Ages & 0,061 & 2,773 & 0,956 & 8,044 \\
\hline Family History & 0,001 & 3,784 & 1,772 & 8,080 \\
\hline Gender & 0,120 & 0,453 & 0,167 & 1,230 \\
\hline
\end{tabular}

TABLE V. LAST MODELS

\begin{tabular}{|l|l|l|l|l|}
\hline \multirow{2}{*}{ Variable } & \multirow{2}{*}{ P Value } & \multirow{2}{*}{ Exp (B) } & \multicolumn{2}{|l|}{ 95\% CI FOR EXP (B) } \\
\cline { 4 - 5 } & & & Lower & Upper \\
\hline Obesity & 0,004 & 2,870 & 1,399 & 5,889 \\
\hline Physical Activity & 0,000 & 4,456 & 2,140 & 9,281 \\
\hline Ages & 0,016 & 3,192 & 1,239 & 8,227 \\
\hline Family History & 0,001 & 3,681 & 1,744 & 7,771 \\
\hline Stress & 0,037 & 2,108 & 1,046 & 4,247 \\
\hline
\end{tabular}

Based on the results of multivariate analysis with multiple logistic regression, the variables significantly related with hypertension were obesity, physical activity, age, family history and stress (Table 5). Variables that have a cause relationwith hypertension in Posbindu District Cipayung are as follows:1) Obesity people risk 2.9 times (95\% OR OR $1,399-5,889)$ suffer from hypertension compared to people who are not obese. 2) People with less physical activity were at risk 4.5 times $(95 \%$ CI OR 2,140-9,281) suffered from hypertension compared to people with moderate physical activity. 3) People aged $\geq 40$ years are at risk 3.2 times $(95 \%$ OR 1,239- 8,227) have hypertension compared with people $<40$ years old. 4) People with family history of hypertension is the greater risk of 3.7 times (95\% CI 1,744 - 7,771) have hypertension compared with people who do not have a family history of hypetension. 5) People who are more at risk of stress 2.1 times (95\% CI OR 1, 046 - 4,247). 6) The counfonding variables are 1) Excessive salt / sodium consumption to obesity variable 2) gender to stress, age, and family history, and 3) Smoking habit to physical activity, stress, and age.

Obesity is related with hypertension [5, 6, 7, 8].Obesity will trigger the occurrence of hypertension because if a person's body weight increases then the volume of blood also increases so the burden of the heart to pump blood also increases [9]. Fat accumulation due to obesity raises plaque that will clog the blood flow so that blood pressure increases $[4,10]$.

Less physical activity can risk of high blood pressure [11, 12]. This can increase the risk of becoming obese. People with less physical activity tend to have a faster heart beat and heart muscle should work harder on every contraction and often. The heart must pump bigger and urgent arteries so that blood pressure will increase.
Increased age may increase the risk of hypertension [7, 13, 14].The addition of age is caused by the thick of the arterial wall by accumulation of connective tissue. At that time it's also decrease in elasticity and densibilitas vessels, so that the aorta becomes stiff. A rigid aorta causes blood-constricted areas during cardiac constriction to be limited, resulting in increased systolic blood pressure without the increase in diastolic blood pressure [15].

People who have hypertension offspring are congenital to suffer from hypertension, the more likely adults are suffering from greater hypertension $[7,16,17]$. When viewed from the side plausibility $(+)$ in theory a person suffering from hypertension, has a genetic factor of his family and at risk of suffering from hypertension. This is related to elevated intracellular sodium levels and low ratio between potassium to sodium Individuals with elderly people with hypertension [4].. If both parents suffer from hypertension, then about $45 \%$ down to his children.

Stress associated of hypertension $[6,18,19,20]$. This is due to hypertension related to sympathetic nervous activity, in conditions stress will increase and affect the blood flow, thus causing the heart to pump blood faster, and it can lead to increased blood pressure [18]. According to the Framingham study, women aged 45-64 years have a number of stresstriggering factors such as tense circumstances, domestic problems, economic stress, daily stress, job mobility, anxiety and buried anger. All of these are associated with increased blood pressure and clinical manifestations of cardiovascular disease. In addition, emotional pressure and activation of the nerve causing increased blood pressure due to vascular arteriolar vascular arterioles post glomerulus resulting in sodium retention with the consequent increase in plasma volume and extra fluid volume of cells affecting the occurrence of hypertension [21]. Individuals living in urban areas with higher levels of stress have a higher risk of hypertension than individuals living in rural areas [19].

\section{CONCLUSION}

The proportion of hypertensive patients who visited Posbindu in Cipayung Puskesmas area in June 2017 was $68,6 \%$. Variables that have a causal relationwith hypertension in Posbindu District Cipayungis as follows: obese, less physical activity, age $\geq 40$ years, have a family history of hypertension, stress. Counfonding variables are excessive salt / sodium consumption, gender, and smoking.

It is suggested that health officers from Cipayung Community Health Center conduct socialization of CERDIK behavior (Regular health check including blood pressure check, Awareness of cigarette smoke, Diligent physical activity, healthy and balanced diet, adequate rest and manage stress) for the community.

\section{REFERENCES}

[1] Ministry of Health, "Republic of Indonesia, Bulletin of NonCommunicable Diseases", 2012.

[2] Ministry of Health, Republic of Indonesia, "Basic Health Research", 2013. 
[3] East Jakarta Health Agency, "The Annual Report of the NonCommunicable Disease Control Program (PTM)", 2016.

[4] Ministry of Health, Republic of Indonesia, "Hypertension Technical Guidelines Jakarta”, 2015.

[5] Hendromartono, Obesitas sebagai faktor Risiko Penyakit Kardiovaskuler. Majalah Kedokteran Udayana, 2012, p.33(116): 91-96

[6] Widyartha J, I.W.G Artawan Eka Putra, Luh Seri Ani, Family history, stress, physical activity mild, obesity and consumption of excess salt as hypertension risk factors. Public Health and Preventive Medicine Archive, vol. 4, 2016, no. 2.

[7] A. Sugiharto, The risk factors of Grade II hypertension in the community. Master Program of Public Health Diponegoro University, Semarang, 2007.

[8] Y. Yeni, Factors-factors associated with the incidence of Hypertension in women of childbearing age in Primary Health Center Umbulharjo I Yogyakarta, Universitas Achmad Dahlan Yogyakarta, 2009.

[9] Buttar H.S, Timao Li, and Ravi N, "Prevention of cardiovascular diseases: Role of exercise, dietary interventions, obesity and smoking cessation", Exp Clin Cardiol, Winter; 10(4): 229-249, 2005.

[10] Jankowski P, Czarnecka D, "Pulse pressure, blood flow, and artherosclerosis", American Journal of Hypertension, vol. 25, Issue 10: 1040-1041, 2012

[11] Paskalia B, Risk Factors of Hypertension Occurrence In Patients in the Internal Disease Room RSUD dr. M. Haulussy Ambon. Global Health Science, Vol. 1 Issue 2, June, 2016.

[12] Mannan H, Risk Factors of Hypertension Incidence in Patients in Primary Health Center Bangkala, Kab. Jeneponto, Public Health Faculty Universitas Hasanuddin, 2012.
[13] Pradetyawan, Age and Gender Relationships with High Blood Pressure at Posbindu in Triyagan Mojolaban Sukoharjo. Medicine Faculty, Universitas Muhammadiyah Surakarta, 2014.

[14] Rustika, Hypertension at Young Lifestyle(internet) http: id.inaheart.or.id// /(accessed 2 Februari 2008).

[15] R. Saryawati, Risk factors of hypertention on textile industry workers. (Thesis). Magister of Enviroment Health, Unversitas Diponegoro, 2008.

[16] M. Hafiz, I wayan Weta, "Factors Associated With Hypertension Occurrence In The Elderly Group at Primary Health Center Petang I Kabupaten Badung Tahun 2016" E-Jurnal Medika, Vol. 5 No.7, Juli, 2016.

[17] Siringoringo, Martati, Hiswani, Jemadi "Factors Associated With Hypertension In Elderly at Sigaol Simbolon District, Samosirin 2013" Departement of Epidemiology Public Helath Faculty, Universitas Sumatera Utara, 2013.

[18] R. P. Sidabutar and Wiguno, Essential Hypertension. in Internal Medicine. vol. 2. Jakarta. Balai Penerbit Medicine Faculty, Universitas Indonesia, 1998.

[19] J. Pradono, Prevalence of Non Communicable Diseases in Indonesia According to STEPS Approach Risk Factors (Data Study Morbidity).Web: <http :// digilib. litbang. depkes.go.id.>, 2003.

[20] D. E. Saputri, Stress Relation with Hypertension in Population Indonesia at 2007 (based on Basic Health Research), Faculty of Public Health Universitas Indonesia, 2010.

[21] E. Sukandar, Essential Hypertension: Pathogenesis, Pathophysiology and Role of Beta - Blocker. Cermin Dunia Kedokteran. No. 19 p. 9$15,1980$. 